\title{
Korupsi Dalam Perspektif Hukum Islam
}

\author{
Oleh: Syamsul Anwar \\ Dosen UIN Yogyakarta \\ e-mail:
}

\begin{abstract}
From shariah point of view, a person caught committing corruption shall be penalized. Beside of this, shariah also recognizes a concept so called by ta'zir, it is an authority granted to a person or a body to exercise criminalization policy on cases where Qur'an and Sunnah do not clearly stipulate. Corruption in a case in point. Hence, a government may possesses the freedom to determine the type of penalty which is considered as in conformity with the condition of the society
\end{abstract}

Keywords: Korupsi, hukum Islam

\section{Pendahuluan}

Masalah korupsi merupakan fenomena kebudayaan manusia yang cukup tua. Barang kali hampir sama tuanya dengan peradaban manusia itu sendiri. Paling tidak dapat diperkirakan bahwa fenomena korupsi sudah muncul dalam peradaban manusia sejak manusia itu mengenal sistem hidup bersama yang terorganisasi, sehingga hampir bisa dikatakan bahwa di mana terdapat suatu sistem hidup bersama yang terorganisasi dan ada korupsi dalam suatu atau lain bentuk.

Di Indonesia korupsi memang merupakan salah satu masalah besar dan pemberantasannya menjadi prioritas program pemerintah sekarang. Kajian tentang korupsi di negara ini dari berbagai aspek juga sudah dilakukan sejak beberapa dasawarsa yang lalu. Hanya saja kajian korupsi dan perlawanan terhadapnya dalam perspektif hukum Islam masih amat langka. Padahal sesungguhnya dalam khazanah syariah terhadap rujukan-rujukan mengenai masalah korupsi yang kiranya layak untuk menjadi bahan renungan. 
Pengembangan pemahaman tentang korupsi dan pemberantasannya dari perspektif hukum syariah sebagai salah satu dari kajian banyak cara yang harus digunakan secara simultan untuk melakukan pemberantasan korupsi memberikan beberapa keuntungan. Di antaranya adalah sifat dari hukum syariah yang bernuansa keagamaan. Pemberantasan korupsi melalui pemanfaatan dan pengembangan wacana hukum bernuansa keagamaan dapat dimanfaatkan sebagai bagian dari keseluruhan upaya pemberantasan korupsi di negari ini, karena di Indonesia suara agama masih cukup didengarkan dan masih mempengaruhi pola laku masyarakat kita. Karena itu tulisan berikut akan mencoba mengekplorasi beberapa rujukan masalah korupsi dalam khazanah syariah (hukum Islam).

\section{Pengertian Korupsi}

Sebelum masuk ke dalam permasalahan pokok yang akan dikaji di sini, terlebih dahulu perlu dijelaskan pengertian, unsur-unsur dan macam-macam atau bentuk-bentuk korupsi. Kata 'korupsi' berasal dari kata Latin corruptus yang berarti suatu yang rusak atau hancur. Dalam pemakaian sehari-hari dalam bahasa-bahasa modern Eropa, seperti bahasa Inggris, kata 'korupsi' dapat digunakan untuk menyebut kerusakan fisik seperti frasa 'a corrupt manuscript (naskah yang rusak)dan dapat juga untuk menyebut kerusakan tingkah laku sehingga menyatakan pengertian tidak bermoral (immoral) atau tidak jujur atau tidak dapat dipercaya (dishonest). Selain itu 'korupsi' juga berarti tidak bersih (impure) seperti frasa corrupt air yang berarti impure air (udara tidak bersih). ${ }^{1}$

Dalam kajian-kajian mengenai korupsi ada beberapa definisi yang dikemukakan oleh para ahli menyangkut terminologi korupsi. Syeh Hussein Alatas menegaskan bahwa "esensi korupsi adalah pencurian melalui penipuan dalam situasi yang mengkhianati kepercayaan'. ${ }^{2}$ Dalam Webster's Third New International Dictionary, korupsi didefinisikan sebagai “ajakan (dari seorang pejabat publik) dengan pertimbangan-pertimbangan yang tidak semestinya

${ }^{1}$ Lihat Horby, oxford Advanced Learner's Dictionary, edisi ke-4 (Oxford: Oxford University Press, 1989), h. 266, entri 'corrupt'.

${ }^{2}$ Alatas, Korupsi: Sifat, Sebab dan Fungsi, alih bahasan Nitworno (Jakarta: LP3ES, 1987), h. viii. 
untuk melakukan pelanggaran tugas". ${ }^{3}$ Menurut Robert Klitgaard korupsi merupakan tindakan berupa (1) memungut uang atas layanan yang sudah seharusnya diberikan, (2) menggunakan wewenang untuk mencapai tujuan yang tidak sah, dan (3) tidak melaksanakan tugas karena lalai atau lupa. ${ }^{4}$ Bank Dunia menganut definisi klasik yang singkat tapi luas cakupannya yang memandang korupsi sebagai the abuse of public office for private gain 'penyalahgunaan jabatan publik untuk memperoleh keuntungan pribadi'. Sementara itu Badan Informasi Internasional di Lebanon menyatakan, "Korupsi adalah perlakuan individu-individu swasta maupun pejabat pemerintah yang telah menyimpang dari tanggung jawab yang telah ditetapkan dengan menggunakan jabatan atau kekuasaan mereka untuk mencapai tujuan pribadi maupun mengamankan kepentingan pribadi".${ }^{6}$ Dengan demikian unsur pokok korupsi itu sesungguhnya tercermin adalam adanya (1) perbuatan menyimpang dari norma, (2) perbuatan itu menimbulkan kerugian kepada negara atau masyarakat meskipun tidak selalu berupa kerugian finansial, misalnya kerugian dalam bentuk buruknya pelayanan umum atau tindakan berjalannya sistem hukum, (3) adanya penyalahgunaan wewenang.

Dari UU No. 31 Tahun 1999 Tentang Pemberantasan Tindak Pidana Korupsi beserta dengan perubahannya ( UU No. 20 Tahun 2001 Tentang Perubahan atas Undang-Undang No. 31 Tahun 1999 tentang Pemberantasan Tindak Pidana Korupsi) dapat disimpulkan bahwa tindak pidana korupsi adalah melakukan secara melawan hukum perbuatan memperkaya diri sendiri atau orang lain atau suatu korporasi yang dapat merugikan keuangan negara atau perekonomian negara. Apa yang tercakup ke dalam tindak pidana korupsi itu menurut UU No. 31/1999 dan perbuatannya UU No. 20/2001 adalah

${ }^{3}$ Dikutip dalam Sudirman Said dan Nizar Suhendra, "Korupsi dan Masyarakat Indonesia", dalam Hamid Basyaib dkk., (ed), Mencuri uang Rakyat: 16 kajian Korupsi di Indonesia Buku 1 (Jakarta: Yayasan Aksara, 2002), h. 98.

${ }^{4}$ Robert Klitgaard dkk., Penuntun Pemberantasan Korupsi dalam Pemerintahan Daerah, alih bahasa Masri Maris (Jakarta: Yayasan Obor dan Patnership for Governance Reform in Indonesia, 2002), h. 3.

${ }^{5}$ Dikutip dalam Sudirman Said dan Nizar Suhendra, "Korupsi dan Masyarakat Indonesia", dalam Hamid Basyaib dkk (ed.), Mencuri Uang Rakyat: 16 Kajian Korupsi di Indonesia Buku 1 (Jakarta: Yayasan Akasara, 2001), h. 99.

${ }^{6}$ Di kutip dalam Singgih, Duniapun Memerangi Korupsi (Tangerang: Pusat Studi Hukum dan Bisnis Universitas Pelita harapan, t.t.), h. 120.

16 
melakukan perbuatan seperti dimaksud dalam Pasal 2, Pasal 3, Pasal 5, Pasal 6, Pasal 7, Pasal 8, Pasal 9, Pasal 10, Pasal 11, Pasal 12, pasal 12 B, Pasal 13, dan Pasal 14.

Korupsi ditandai oleh ciri-ciri berupa (1) adanya pengkhianatan kepercayaan, (2) keserbarahasiaan, (3) mengandung penipuan terhadap badan publik atau masyarakat, (4) dengan sengaja melalaikan kepentingan umum untuk kepentingan khusus, (5) diselubungi dengan bentuk-bentuk pengesahan hukum, (6) terpusatnya korupsi pada mereka yang menghendaki keputusan pribadi dan mereka yang dapat mempengaruhinya. ${ }^{7}$ Ada beberapa jenis atau macam korupsi. Menurut Alatas, jenis tersebut meliputi pertama, korupsi transaksi, yaitu jenis korupsi yang berwujud adanya kesepakatan timbul balik antara pihak-pihak bersangkutan guna mengupayakan keuntungan bersama. Korupsi jenis ini biasanya terjadi antara usahawan dengan pejabat pemerintah atau anggota masyarakat dan pemerintah. Kedua, korupsi ekstortif (memeras), yaitu bentuk korupsi di mana pihak pemberi dipaksa melakukan perbuatan penyuapan guna mencegah kerugian yang akan mengancam diri, kepentingan, orang-orang atau hal-hal yang penting baginya.Ketiga, korupsi defensif, yaitu korupsi yang dilakukan oleh pelaku korban korupsi pemerasan. Keempat, korupsi keuntungan tertentu, selain dari keuntungan yang dibayangkan di masa depan. Kelima, korupsi nepotistik (perkerabatan), yaitu kolusi berupa penunjukan tidak sah terhadap teman atau kerabat untuk menempati posisi dalam pemerintahan, atau memberi perlakukan istimewa kepada mereka secara bertentangan dengan norma yang berlaku. Keenam, korupsi otogenik, yaitu yang dilakukan sendirian tanpa melibatkan orang lain, misalnya membuat laporan belanja yang tidak benar. Ketujuh, korupsi suportif (dukungan), yaitu tindakan yang dimaksudkan untuk melindungi atau memperkuat korupsi yang sudah ada. ${ }^{8}$

Dapat pula ditambahkan jenis korupsi kedelapan yang akhir-akhir ini berkembang ke permukaan, yaitu suatu jenis korupsi yang disebut korupsi legal, yaitu suatu kebijakan yang secara hukum adalah sah karena sesuai dengan ketentuan peraturan yang berlaku, namun sesungguhnya pada dasarnya merupakan suatu korupsi bila dilihat dari sudut visi penyelenggaraan

${ }^{7}$ Alatas, Sosiologi Korupsi: Sebuah Penjelajahan dengan Data Kontemporer, alih bahasa Al Ghozie Usman (Jakarta: LP3ES, 1975), h. 13.

${ }^{8}$ Alatas, Korupsi, h. ix-x. 
kepemerintahan yang baik. Termasuk ke dalam kategori ini adalah apa yang disebut dengan korupsi demokratis, yaitu kebijakan yang disahkan oleh legislatif, namun bertentangan dengan visi yang benar dari kepemerintahan yang baik. Misalnya penganggaran rumah dinas pejabat yang jauh lebih besar dari anggaran pembangunan gedung sekolah dasar.

\section{Rujukan Mengenai Korupsi Syariah}

\section{Dalam al-Quran}

Dalam al-Quran terdapat pembicaraan mengenai tindakan-tindakan yang dapat dipandang sebagai korupsi.

a. Firman Allah dalam surat al-Baqarah ayat 188,

$$
\text { و لا تأ كلو ا أمو الكم بينكم بالباطل وتدلو ا بها الي الحكام لتأكلو ا فريقا من أمو ال الناس بالإثم وأنتم تعلمون }
$$

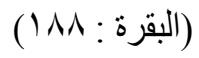

Artinya: Dan janganlah kamu memakan harta sesama di antara kamu dengan jalan yang batil dan (janganlah) kamu membawa (urusan) harta itu kepada hakim, supaya kamu dapat memakan sebahagian daaripada harta benda orang lain itu dengan (jalan berbuat) dosa, padahal kamu mengetahui (Q 2: 188)

Dalam ayat ini dilarang makan harta sesama dengan jalan batil, yaitu dengan cara membawanya kepada pihak penguasa, di antaranya haki, dengan menyogoknya agar dimenangkan perkaranya sehingga ia dapat menguasai kekayaan tersebut. Frasa 'makan harta sesama dengan jalan batil' di sini merupakan perbuatan memperkaya diri sendiri, orang lain atau korporasi secara bertentangan dengan hukum (syariah).

b. Dalam Surat Ali Imran ayat 161

وما كان لنبي أن يظلل يأت بما غل يوم القيامة ثم توفى كل نفس ما كسبت وهم لا يظلمون (ال عمران : (17 )

Artinya: Tidak mungkin seorang nabi melakukan gulul (berkhianat dalam urusan harta kekayaan). Barang siapa yang melakukan gulul (berkhianat dalam urusan harta kekayaan), maka pada hari kiamat ia akan datang membawa apa yang digululnya (dikhianatkan itu); kemudian tiap-tiap diri akan diberi pembalasan tentang apa yang ia kerjakan dengan (pembalasan) setimpal, sedangkan mereka tidak dirugikan [Q. 3: 161]. 
Dalam ayat ini rujukan kepada korupsi dilakukan dengan menggunakan kata gulul. Secara harfiah gulul berarti pengkhianatan terhadap kepercayaan (amanah). Memang, seperti ditegaskan oleh Syeh Hussein Alatas, seorang pemerhati fenomena korupsi, "inti korupsi adalah penyalahgunaan kepercayaan untuk kepentingan pribadi" atau "pencurian melalui penipuan dalam situasi yang mengkhianati kepercayaan". ${ }^{9}$

Pada umumnya para ulama menghubungkan ayat 161 Ali Imran dengan peristiwa pada Perang Uhud yang terjadi pada tahun ke-3 H. Dalam peristiwa ini, strategi Nabi saw adalah menempatkan pasukan pemanah pada posisi di atas bukit di belakang pasukan Rasulullah dan pasukan pemanah itu bertugas melindungi pasukan Rasulullah di bawah bukit dari serangan pasukan Musyrikin dari belakang. Pada awalnya pasukan Muslimin berhasil mengalahkan pasukan Musyrikin dan mereka lari kucar kacir. Melihat kemenangan itu pasukan pemanah di atas bukit meninggalkan posisi mereka untuk berebut rampasan perang sehingga akibatnya kemudian kemenangan mereka berubah menjadi kekalahan. ${ }^{10}$ Ketika mereka melihat turun, sebagaimana ditegaskan dalam kitab al-'Ijab, nabi saw berkata: "Bukankah saya lebih perintahkan kepada kalian agar tidak meninggalkan posisi sampai ada perintah saya lebih lanjut?" Mereka menjawab, "Masih ada beberapa teman kita berdiri di sana". Pada waktu itu Nabi berkata, "sebenarnya kalian pasti mengira bahwa kami melakukan gulul". ${ }^{11}$ Untuk menyangggah anggapan itu, maka turunlah ayat 'wa maa kaana linabiyyin an yagulla...' [Q. 3: 161], yang oleh at-Tabari ditafsirkan, "Bukanlah sifat para nabi untuk melakukan gulul dan orang yang melakukan gulul bukanlah nabi". ${ }^{12}$

Syihabuddin Abu al-Fadl menyebutkan bahwa al-Kalbi (w.146/763) dalam tafsirnya juga menyebutkan riwayat yang sama dengan sedikit perbedaan kalimat, di mana dalam kalimatnya "Kami khawatir

${ }^{9}$ Alatas, Korupsi, Sifat, Sebab dan Fungsi, alih bahasa Nirwono (Jakatrta: LP3ES, 1987), h. Vii dan h, viii.

${ }^{10} \mathrm{Ibn}$ al-Qayyim, Zad al-Ma'ad (ttp.: Dar al-Fikr, t.t.), II: 93.

${ }^{11}$ Sama dengan catatan kaki no. 15

${ }^{12}$ At-tabari, op.cit., IV: 157. 
Rasulullah saw tidak membagikan ganimah seperti halnya tidak ia lakukan pada waktu Perang Badar", dan ia menambahkan sesudah frasa '... bahwa kami melakukan gulul' kata-kata 'dan tidak membagikan ganimah untuk kalian'. Al-Wahidi (w.468/1075) menggabungkan kedua riwayat tersebut menjadi satu. ${ }^{13}$ Meskipun muqatil (w.150/766) dan al-Kalbi (w. 146/763) terbilang periwayat tafsir ibn 'Abbas yang dianggap lemah, namun riwayat mereka ini cocok dengan konteks ayat bersangkutan, yaitu Perang Uhud dan para ulama hampir sepakat bahwa ayat tersebut memang turun menyangkut perang tersebut. Lagi pula Muqatil dan al-Kalbi banyak dikutip oleh para ahli tafsir yang kemudian. Beberapa rawi terpercaya seperti Sufyan as-Sauri (w. 161/778) dan Muhammad Ibn Fudail Ibn Gazwan (w.195/ 810) meriwayatkan dari al-Kalbi. ${ }^{14}$

Dengan memperhatikan riwayat di atas dan memperhatikan tafsir yang diberikan oleh al-Tabari (w. 310/923) terhadap ayat 161 Ali Imran, dapat dilihat bahwa dalam Perang Uhud sebenarnya tidak ada korupsi yang terjadi. Yang ada adalah anggapan atau sangkaan dari pasukan pemanah di atas bukit bahwa pasukan yang dipimpin Nabi saw di bawah bukit akan melakukan gulul saat mereka berhasil mengalahkan pasukan kaum Musyrikin.

Poin yang hendak dicatat di sini adalah makna gulul itu sendiri. Dari ungkapan Nabi saw, "Kamu sebenarnya mengira kami melakukan gulul dan tidak membagikan ganimah untuk kamu", terlihat bahwa pengertian gulul adalah kebijakan pembagian ganimah yang tidak sebagaimanana mestinya, menyimpang dari ketentuan yang ada. Dengan kata lain gulul (korupsi) dalam konteks ini adalah pembuatan kebijakan yang menyimpang dari yang semestinya. Pengertian ini sejalan atau menyerupai bentuk kedelapan dari korupsi yang dikemukakan terdahulu.

c. Dalam surat al-Maidah ayat 42,62 , dan 63,

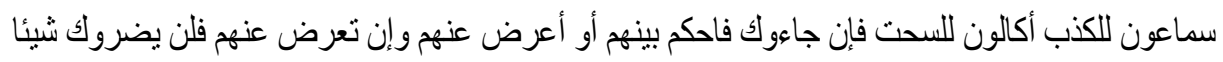

${ }^{13}$ Al-Wahidi, op.cit., h. 84-5

${ }^{14}$ Syihabuddin Abu al-Fadl, op.cit., I:210 


$$
\text { و إن حكمت فحكم بينهم بالقسط إن الله يحب المقسطين ( المائدة : Y § ) }
$$

Artinya: Mereka itu adalah orang-orang yang suka mendengar berita bohong, banyak memakan yang haram. Jika mereka (orang Yahudi) datang kepadamu (untuk meminta putusan) maka putuskanlah (perkara itu) di antara mereka, atau berpalinglah dari mereka; jika kamu berpaling dari mereka tidak akan memberi mudharat kepadamu sedikitpun. Dan jika kamu memutuskan perkara mereka, maka putuskanlah (perkara itu) di antara mereka dengan adil, sesungouhnya Allah menyukai orang-orang yang adil. [Q. 5:42]

وترى كثير ا منهم يسار عون في المإثم و العدو ان و أكلهم السحت لبئس ما كانو ا يعملون • لو لا لا ينهاهم

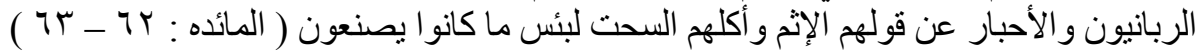

Artinya: Dan kamu akan melihat kebanyakan dari mereka (orang-orang Yahudi) bersegera membuat dosa, permusuhan dan memakan yang haram. Sesungguhnya amat buruk apa yang mereka telah kerjakan itu. Mengapa orang-orang alim dan pendeta-pendeta mereka tidak melarang mereka mengucapkan perkataan bohong dan memakan yang haram? Sesungguhnya amat buruk apa yang telah mereka kerjakan itu. [Q. 5:62-63]

Dalam ayat-ayat ini rujukan kepada korupsi dilakukan dengan menyebut akl as-suht 'makan yang haram'. Dalam kitab tafsir Ahkam al-Quran dikutip definisi Sahabat Ibn Mas'ud (w. 32/652) tentang assuht sebagai "menjadi perantara dengan menerima imbalan antara seseorang dengan pihak penguasa untuk suatu kepentingan". ${ }^{15}$ Khalifah Umar Ibn al-Khattab (w. 24/644) mengemukakan pengertian yang sama dengan Ibn Mas'ud di mana ia menyatakan, 'As-suht adalah bahwa seseorang yang memiliki pengaruh di lingkungan sumber kekuasaan menjadi perantara dengan menerima imbalan bagi seorang lain yang mempunyai kepentingan sehingga penguasa tadi meluluskan keperluan orang itu. ${ }^{16}$ Ini artinya ada unsur penggunaan jabatan atau kekuasaan atau kewenangan untuk memperkaya diri atau orang lain atau suatu korporasi dengan menerima imbalan dari orang lain atas perbuatan itu.

${ }^{15}$ Al-Jashshash, Ahkam al-Quran (Bairut: Dar Ihya' at-Turas al-Arabiy, 1405 H), 4:84.

${ }^{16}$ Ibid., 4:85. 


\section{Dalam Hadis Nabi saw.}

Dalam hadis-hadis Nabi saw terdapat lebih banyak rujukan mengenai korupsi baik menyangkut apa yang termasuk ke dalam kategori korupsi maupun upaya Nabi saw dalam melakukan pemberantasan koruspi. Dalam hadis-hadis beliau korupsi disebut gulul. Tentang apa yang termasuk korupsi dapat dikemukakan sebagai berikut.

a. Hadiah kepada pejabat

$$
\text { عن أبي حميد الساعدي أن رسول الهه صلي الله عليه وسلم قال هدايا العمال غلول (رو اه أحمد) }
$$

Artinya: Dari Abu Humaid as-Sa'idi (diriwayatkan) bahwa Rasulullah swa berkata: Pemberian hadiah kepada para pejabat adalah korupsi (gulul). [HR. Ahmad] ${ }^{17}$

Menurut Ibn Hajar, hadis pendek Ahmad ini diriwayatkan melalui Ismail Ibn 'Ayyasy (w. 181/797) dari Yahya Ibn Sa'id (w. 144/761) dan merupakan ringkasan atau riwayat dengan makna dari hadis panjang di atas. ${ }^{18}$ Hadis ini dengan tegas menyatakan hadiah yang diterima pejabat dari masyarakat yang dipandang sebagai salah satu bentuk korupsi dan tidak boleh diterima. Yang dimaksud dengan hadiah di sini menurut para pensyarah hadis dan ulama fikih adalah pemberian yang diterima seseorang pejabat atau pegawai (petugas) yang terkait atau patut diduga terkait dengan jabatannya. An-Nawawi (w. 676/1277) menyatakan, “Dalam hadis ini Nabi saw menjelaskan sebab diharamkannya menerima hadiah (pemberian), yaitu keterkaitannya dengan jabatan. Lain halnya dengan hadiah kepada bukan pejabat (petugas), hadiah semacam itu dianjurkan" ${ }^{19}$ Bila dilacak secara lebih jauh pengertian hadiah (pemberian) dalam kedua hadis di atas mencakup pula suap (risywah). Mengomentari hadis ini, asySyafi'i (w.204/820) dalam al-Umm mengatakan, Apabila seorang warga masyarakat memberikan hadiah kepada seorang pejabat, maka bilamana hadiah itu dimaksudkan untuk memperoleh, melalui atau dari pejabat itu, suatu hak atau suatu yang batil, maka haram atas pejabat bersangkutan untuk menerima hadiah tersebut. Hal itu karena adalah haram atasnya

${ }^{17}$ Ahmad, op.cit., $\mathrm{V}: 424$.

${ }^{18}$ Ibn Hajar, Fath al-Bari (Beirut: Dar al-Ma' rifah, 1379), V: 221 dan XIII: 164.

${ }^{19}$ An-Nawawi, Syarh an-Nawawi 'ala Sahih Muslim (Beirut: Dar Ihya at-Turas al-Arabi, 1392 H), XII: 219). 
untuk mempercepat pengambilan hak (yang belum waktunya) untuk kepentingan orang yang ia menangani urusannya (dengan menerima imbalan) karena Allah mewajibkan mengurus hak dan imbalan atas pengambilan suatu yang batil itu lebih haram lagi. Demikian pula (haram atasnya) apabila ia menerima hadiah itu dengan menghindarkan pemberian hadiah dari suatu yang ia ingini. Adapun apabila ia dengan menerima hadiah itu bermaksud menghindarkan pemberian hadiah dari suatu kewajiban yang harus ditunaikannya, maka haram atas pejabat tersebut menghindarkan pemberian hadiah dari kewajiban yang harus dilakukannya. ${ }^{20}$

Pernyataan asy-Syafi'i ini memuat beberpa bentuk hadiah haram yang mungkin diterima pejabat (pegawai) dari pemberian hadiah, yaitu:

1) hadiah dari pemberi dengan maksud si pemberi mendapat haknya lebih cepat dari waktunya yang semestinya;

2) hadiah dari pemberi dengan maksud si pemberi memperoleh sesuatu yang bukan haknya, seperti hakim menerima suap dari tergugat atau terdakwa agar kasusnya dimenangkan atau dibebaskan dari tuntutan hukuman, pada hal bukti-bukti sebenarnya menunjukkan sebaliknya;

3) hadiah dari pemberi dengan maksud pejabat bersangkutan membebaskannya dari seluruh atau sebagian kewajiban yang seharusnya ia tunaikan, seperti hadiah yang diterima petugas pajak dari wajib pajak agar kewajiban pajaknya diperkecil;

4) hadiah yang dikategorikan sebagai korupsi ekstrotif (pemerasan), yaitu bentuk korupsi dimana pihak pemberi dipaksa melakukan penyuapan guna memcegah kerugian yang akan mengancam diri, kepentingan, orang-orang atau hal-hal yang penting baginya.

Keempat bentuk pemberian hadiah yang disebutkan asy-Syafi'i ini disebut sesungguhnya risywah (boleh juga dibaca rusywah atau rasywah). Para ulama juga memasukkan pemberian seseorang kepada petugas atau pejabat untuk mendapatkan haknya sendiri yang terhalang atau untuk menolak suatu yang batil sebagai pemberian yang tidak sah, dan pemberian semacam ini, menurut sementara ulama, dinamakan as-suht. ${ }^{21}$ Memang ada juga pendapat yang membenarkan orang menyogok untuk mendapatkan haknya

${ }^{20}$ As-Syafi'I, Al-Umm (Beirut: Dar al-Fikr, 1990) Juz II: 63.

${ }^{21}$ Asy-Syaukani, Nail al-Autar (Beirut: Dar al-Jil, 1973), IX: 172. 
yang sah atau untuk menolak suatu yang batil, bahkan boleh menerima sogok untuk melakukan suatu yang tidak wajib dikerjakannya sebagai pejabat atau petugas. Namun pendapat ini, menurut asy-Sayukani adalah suatu pendapat yang amat bobrok (fi gayatis-sukut). ${ }^{22}$ Pada zaman sekarang dalam konteks Indonesia, faham seperti ini akan ikut mendorong lajunya korupsi. Pemberian semacam ini, meskipun dilakukan oleh pemberi untuk mendapatkan haknya yang sah, akan membawa dampak merusak kepada sistem pelayanan publik berupa memburuknya kualitas pelayanan tersebut.

عن ثوبان قال لعن رسول الله (ص) الر اشي و المرتشي و الر ائش يعني الذي يمشي بينهما (رواه أحمد)

b. Risywah

Artinya: DariSauban (diriwayatkan bahwa) ia berkata: Rasulullah saw melaknat pelaku, penerima, dan perantara risywah, yaitu orang yang menjadi penghubung di antara keduanya [HR. Ahmad]. ${ }^{23}$

Dalam hadis ini penyuapan merupakan perbuatan yang dilarang dan da[at dikategorikan korupsi. Pelakunya tidak hanya yang menyuap, tetapi juga meliputi penerima suap dan perantara antara penyuap dan penerima suap. Penerima suap di sini adalah pejabat atau petugas yang menyelenggarakan pelayanan publik.

c. Penggelapan

عن زيد بن خالد الجهني أن رجلا من أصحاب النبي صلي الله عليه وسلم توفي يوم خييرفذكرو اذاللك لرسول الله

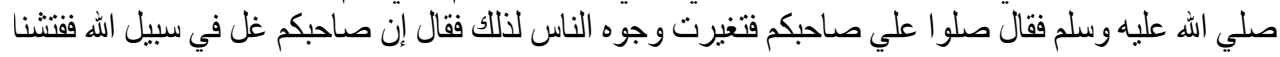

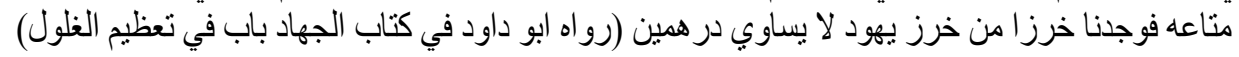

Artinya: Dari Zaid Ibn Khalid al-Juhani bahwa seorang Sahabat Nabi saw meninggal pada waktu penaklukan Khaibar, maka para Sahabat melaporkan hal itu kepada Rasulullah saw. Lalu beliau bersabda:'Shalatkanlah kawanmu itu". Maka berubahlah wajah orang-orang karena sabda tersebut. Kemudian Rasulullah saw bersabda: 'Rekanmu itu telah melakukan gulul dalam perang'. Maka kamipun memeriksa barang-barangnya, lalu kami temukan manik-manik orang yahudi

\footnotetext{
${ }^{22}$ Ibid., IX: 173.

${ }^{23}$ Ahmad, op.cit., V: 279.
} 
yang harganya tidak mencapai dua dirham [HR. Abu Dawud dalam Kitab alJihad, Bab fi Ta'zim al-Gulul"]. ${ }^{24}$

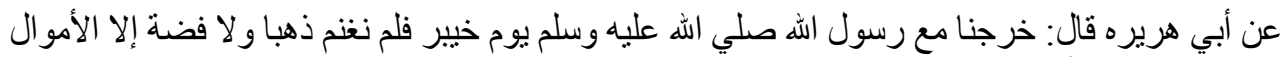

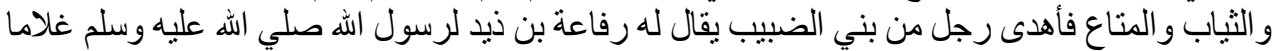

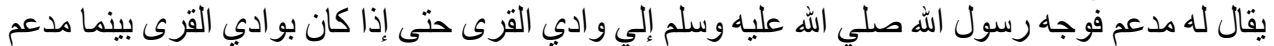

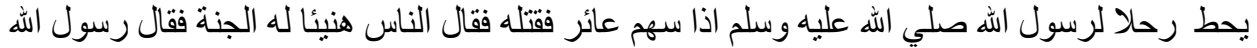

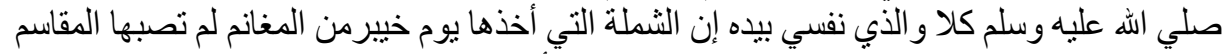

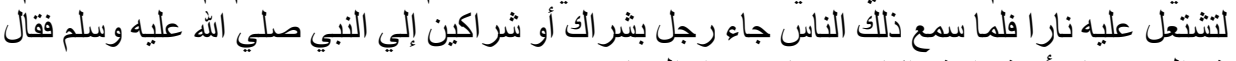
شر الك من نار أو شر اوشر اكان من نار (رو اه البخاري)

Artinya: Dari Abu Hurairah (bahwa)ia berkata: kami keluar bersama Rasulullah saw pada waktu penaklukan Khaibar. Kami tidak memperoleh rampasan perang berupa emas dan perak. Yang kami peroleh benda tak bergerak, pakaian dan barang-barang, dan seorang laki-laki dari Bani ad-Dubaib, bernama Rafi'ah Ibn Zaid menghadiahi Rasulullah saw seorang budak bernama Mid'am. Rasulullah saw berangkat menuju Wadi al Qura, sehingga ketika ia sampai di Wadi alQura itu pada saat Mid'am menurunkan barang-barang bahwa Rasulullah saw tiba-tiba sebuah panah misterius (mengenai Mid'am) sehingga menyebabkan ia meninggal. Maka orang-orang (yang melihat) mengatakan: semoga ia masuk syurga. Maka Rasulullah saw bersabda: Tidak! Demi Tuhan yang diriku di tangan-Nya, sesungguhnya mantel yang diambilnya pada waktu penaklukan Khaibar dari rampasan perang yang belum dibagi akan menyulut api neraka yang akan membakarnya. Ketika orang-orang mendengar pernyataan Rasulullah itu, seorang lelaki datang kepada Nabi saw membawa suatu tali sepatu atau dua utas tali sepatu (keraguan dari rawi). Nabi saw lalu mengatakan: Seutas tali sepatu sekalipun akan menjadi api neraka atau dua utas tali sepatu akan menjadi api neraka (seandainya tidak dikembalikan). [HR. Al-Bukhari]. ${ }^{25}$

\footnotetext{
${ }^{24}$ Abu Dawud, op.cit., I: 626.

${ }^{25}$ Al-Bukhari, Sahih al-Bukhari (Beirut: Dar al Ibn Kasir, 1987), VI: 2466, hadis no. 6329. Perlu dicatat mengenai hadis bahwa Abu Hurairah tidak berangkat ke Khaibar bersama Rasulullah saw sebagaimana diisyaratkan oleh pernyataan abu Hurairah dalam hadis "Kami bersama rasulullah saw pada waktu itu penaklukan Khaibar". Ia datang ke Khaibar belakangan dan menyusul kemudian setelah penaklukan Khaibar selesai. Para ahli hadis menyatakan kekeliruan dalam teks hadis di atas menyenai pernyataan Abu Hurairah bersumber dari Saur Ibn Zaid ad-Dili (w. 135/753). Lihat Ibn Mandah, al-Imam (Beirut: Mu'assasah as -Risalah, 1406), 668-669.
} 
Hadis-hadis di atas merekam dua kasus korupsi. Kasus pertama adalah sebuah kasus korupsi kecil yang dilakukan oleh salah seorang Sahabat yang ikut dalam penaklukan Khaibar. Ia melakukan korupsi terhadap rampasan perang Khaibar dengan cara melakukan penggelapan. Jumlahnya tidak mencapai dua dirham - suatu jumlah yang kecil. Mata uang dirham di zaman Nabi saw nilainya sama dengan sepersepuluh dinar. Satu dinar adalah 4,25 gram emas murni. Jadi dua dirham berarti $2 \times 0,425$ gram emas $=0,85$ gram. Apabila dirupiahkan dengan mengasumsikan harga emas per gram adalah Rp. 100.000,0, maka korupsi di Khaibar tersebut hanya sekitar Rp. 85.000,- Periwayat hadis ini meskipun hanya mengangkut korupsi kecil dimaksudkan untuk menunjukkan beratnya dosa korupsi walaupun jumlah nominalnya kecil. Abu Dawud menempatkan hadis ini di bawah judul "Bab fi Ta'zim al-Gulul" (Bab Tentang Beratnya [Dosa] Korupsi). Dalam kasus ini korupsi diberi hukuman moral, yaitu Rasululaah saw tidak menyalatkan jenazahnya; beliau menyuruh Sahabatnya saja yang menyalatkannya.

Kasus kedua dari korupsi di Khaibar adalah korupsi mantel dan korupsi tali sepatu. Korupsi mantel dilakukan oleh Mi'dam, seorang budak yang mengikuti perjalanan Nabi saw ke Wadi al-Qura beberapa waktu setelah penaklukan Khaibar. Ia terkena tembakan anak panah misterius di Wadi al-Qura ketika hendak menurunkan barang-barang bawaan Rasulullah dari untanya sehingga ia meninggal dunia. Para Sahabat yang melihat kejadian itu mengatakan "Semoga ia masuk Syurga". Namun Nabi saw menyanggah dan menerangkan bahwa ia pernah melakukan korupsi mantel pada waktu penaklukan Khaibar dan mantel yang dikorupsi itu akan membakarnya di neraka kelak. Korupsi tali sepatu pada waktu penaklukan Khaibar dilakukan oleh salah seorang yang ikut dalam perjalanan ke Wadi al-Qura tersebut. Identitasnya secara jelas tidak ada informasinya. Ketika mendengar pernyataan Rasulullah saw mengenai mantel yang dikorupsi oleh $\mathrm{Mi}^{\prime}$ dam dapat menjadi penyebab ia masuk neraka, lelaki itu buru-buru memberikan tali pengikat sepatu yang dikorupsinya pada waktu penaklukan Khaibar kepad Rasulullah saw. 
d. Pemanfaatan Secara Tidak Sah Terhadap Kekayaan Publik

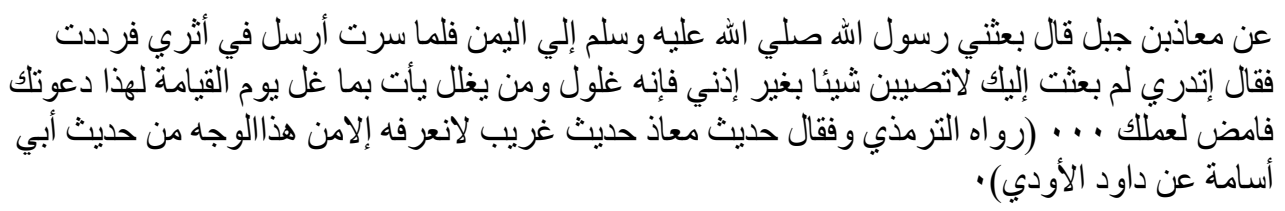

Artinya: Dari Mua'az Ibn Jabal (diriwayatkan bahwa) ia berkata: Rasulullah saw mengutus saya ke Yaman. Ketika saya baru berangkat, ia mengirim seseorang untuk memanggil saya kembali, maka sayapun kembali. Maka beliau berkata: Apakah engkau tahu mengapa saya mengirim orang untuk menyuruhmu kembali? Jangankan kamu mengambil sesuatu apapun tanpa izin saya, karena hal itu adalah gulul, dan barang siapa melakukan gulul, maka ia akan membawa barang yang digulul itu pada hari kiamat. Untuk itulah saya memanggilmu. Sekarang berangkatlah untuk tugasmu. [HR. At-Tirmizi]. ${ }^{26}$

Sejalan dengan hadis $\mathrm{mMu}^{\prime} \mathrm{az}$ ini adalah tindakan seseorang yang mengambil sesuatu/penghasilan di luar gaji yang telah ditetapkan. Dalam hal ini Nabi saw memberikan penegasan,

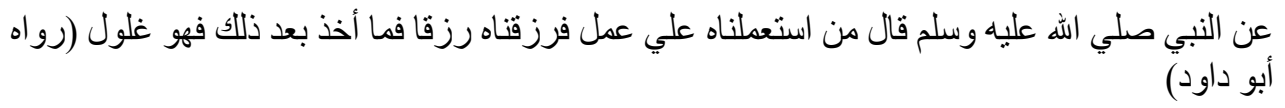

Artinya: barang siapa yang telah aku angkat sebagai pekerja dalam satu jabatan kemudian aku beri gaji, maka sesuatu yang diterima di luar gajinya adalah korupsi (ghulul) [HR Abu Daud].

Dalam hadis ini pengertian gulul tidak lagi dibatasi pada korupsi harta rampasan perang, melainkan sudah diperluas mencakup semua apa saja kekayaan publik yang diambil oleh seorang pejabat secara tidak sah. Dalam hadis ini, terlihat Rasulullah saw memperingatkan Mu'az yang beliau angkat sebagai gubernur di Yaman agar tidak mengambil sesuatu apapun dari kekayaan negara yang ada di bawah kekuasaannya tanpa izin Rasulullah saw (dalam arti tanpa berdasarkan ketentuan hukum yang berlaku). Bilamana hal seperti itu dilakukan, maka itu disebut gulul.

Pesan Rasulullah saw kepada Mu'az adalah wajar belaka karena ada

${ }^{26}$ At-Tirmizi, op.cit., III: 621, No. 1335, “Bab Ma Ja'a fi Hadaya al-Umara'; al Bazzar, op.cit.,VII: 118, No. 2673; at-Tabrani, op.cit., XX: 128 no. 259. Dalam Illah al Tirmizi" dikatakan bahwa hadis ini adalah hadis hadis. Lihat Abu Talin al-Qadi, "ilal at-Qadi, Ilal et-Tirmizi (Beirut: 'Alam a Kutub, 1409), h. 199 
kecenderungan pejabat daerah melakukan korupsi terhadap kekayaan negara dalam suatu atau lain bentuk. Dalam kaitan ini dikenal kasus 'Abdullah Ibn al-Lutbiyyah (atau Ibn al-Atbiyyah) yang diangkat oleh Rasulullah saw sebagai pejabat menarik zakat di Distrik Bani Sulaim pada tahun $9 \mathrm{H}$ yang melakukan korupsi terhadap harta zakat yang dikumpulkannya.

e. Melindungi Perbuatan Korupsi adalah Korupsi

$$
\begin{aligned}
& \text { عن سمرة بن جندب قال أما بعد وكان رسول الله صلي الله عليه وسلم يقول ثم من كتم غالا فإنه مثله (رو اه } \\
& \text { أبو داود و اللفظ له و الطبر اني) }
\end{aligned}
$$

Artinya: Dari Samurah Ibn Jundub (diriwayatkan bahwa) ia berkata: Adapun selanjutnya, Rasulullah saw bersabda: Barangsiapa menyembunyikan koruptor, maka ia sama dengannya [HR Abu Dawud dan at-Tabrani]. ${ }^{27}$

Dalam hadis ini dinyatakan bahwa orang yang melindungi koruptor adalah koruptor, begitu pula perbuatan melindungi koruptor itu adalah perbuatan korupsi. Melindungi dilakukan dengan cara menyembunyikan atau dengan cara memanipulasi hukum sehingga koruptor itu terbebas dari jeratan hukum.

f. Melumpuhkan beroperasinya sistem hukum

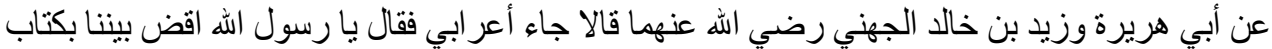

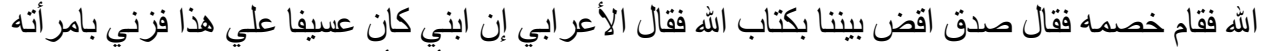

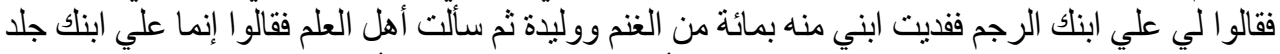

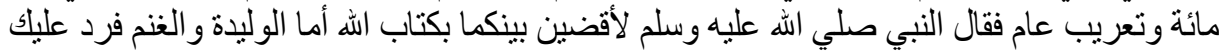

$$
\begin{aligned}
& \text { و علي ابنك جلد مائة وبغريب عام ل... (رو اه البخاري) }
\end{aligned}
$$

Artinya: Dari Abu Hurairah dan Zaid Ibn Khalid al-Juhani r.a. (diriwayatkan bahwa) mereka berkata: Seorang Arab pedalaman datang kepada Nabi saw dan berkata: Wahai Rasulullah, berilah keputusan kepada kami berdasarkan Kitab

${ }^{27}$ Abu Dawud, op.cit., I: 628, hadis no. 2716, "Kitab al-Jihad, Bab an-Nahyu 'an asSatr 'ala Man Galla"; dan at-tabrani, al-Mu'jam al-Kabir (Mousul: Maktabah al-'Ulum wa al-Hikam, 1983), VII: 251, hadis no. 7023. Meskipun tiga rawi Ja'faar, Khubaib dan ayahnya Sulaiman oleh sebagian ahli hadis dinyatakan majhul, namun Ibn Hibban memasukkan ketiganya dalam daftar orang-orang siqah (terpercaya, reliabel). Lihat Ibn Hibban, as-Siqat, VI: 137, no. 7063; VI: 274, no. 7706; dan IV: 314, no. 3076. 
Allah (hukum syariah). Lalu lawan perkaranya berdiri dan berkata: Benar beri keputusan di antara kami berdasarkan Kitab Allah. Orang Arab pedalaman tadi berkata: Anak lelaki saya adalah pekerja di rumah keluarga orang ini (lawan perkaranya), lalu berbuat mesum dengan istrinya. Masyarakat mengatakan, anak saya harus di rajam. Lalu aku menebus dengan 100 ekor kambing dan seorang sahaya perempuan. Kemudian aku bertanya kepada para ahli ilmu, dan mereka mengatakan: Anakmu harus dihukum cambuk (dera) 100 kali cambuk dan dibuang (diasingkan) selama satu tahun. Maka Nabi saw bersabda: Aku akan putuskan di antara kamu berdasarkan Kitab Allah. Sahaya perempuan dan 100 ekor kambing itu dikembalikan kepadamu, dan anakmu harus dihukum cambuk 100 cambuk dan diasingkan selama satu tahun... [HR al-Bukhari].

Menurut Ibn Taimiah (w. 728/1328) perbuatan menyogok oleh sang ayah agar anaknya tidak dilaporkan kepada yang berwajib oleh orang yang istrinya dizinai oleh anaknya (meskipun kemudian dilaporkan juga) adalah korupsi juga, meskipun di situ tidak ada kerugian perekonomian negara atau keuangan negara yang terjadi. Perbuatan itu dikatakan korupsi adalah karena perbuatan memberi 100 ekor kambing itu menyebabkan sistem hukum lumpuh dan tidak berjalan. ${ }^{28}$

\section{Pemberantasan Terhadap Korupsi}

Dari data hadis tentang kasus korupsi, dapat dilihat bahwa Nabi saw tampaknya tidak melakukan kriminalisasi perbuatan korupsi yang terjadi di zamannya. Dalam menangani korupsi tampak lebih banyak melakukan pembinaan moral dengan menanamkan kesadaran untuk menghindari perbuatan korupsi dan mengingatkan hukuman ukhrowi yang akan ditimpakan kepada pelakunya. Dengan berbagai kesempatan Nabi saw mengingat bahwa pelaku korupsi akan masuk neraka sekalipun jumlah nominal korupsinya amat kecil seperti seutas tali sepatu atau sebuah mantel. Barangkali karena jumlah nominal korupsi yang dilakukan di zamannya amat kecil, Nabi saw tidak melakukan pendekatan kriminalisasi tindakan korupsi.

Namun demikian dalam hukum syariah tidak berarti bahwa perbuatan korupsi tidak dapat dipidana. Dalam syariah ada sistem pidana takzir, yaitu

\footnotetext{
${ }^{28}$ Ibn Taimiah, al-Fatawa, XXVIII: 31.
} 
suatu kewenangan yang diberikan kepada pemilik kewenangan untuk melakukan kebijakan kriminalisasi terhadap kejahatan yang dalam al-Quran dan Sunnah Nabi saw tidak ditentukan pidananya, seperti kasus korupsi ini. Selain karena nominal korupsi di zaman Nabi saw kecil, mungkin juga beliau dengan sengaja untuk menyerahkan kepada kebijakan umatnya sendiri untuk melakukan kriminalisasi korupsi sesuai dengan perkembangan tarap kehidupan masyarakat di zaman masing-masing.

Beberapa strategi yang dilakukan Nabi saw dalam mengantisipasi kemungkinan terjadinya korupsi, seperti dapat dibaca dalam data hadis, adalah melakukan pemeriksaaan terhadap para pejabat seusai menjalankan tugas seperti disebutkan dalam beberapa hadis. Selain itu Rasulullah saw berupaya menimbulkan suatu efek psikologis sedemikian rupa sehingga masyarakat sangat menakuti korupsi. Hal ini dilakukan misalnya dengan penolakan Nabi saw untuk menyalatkan jenazah koruptor (cukup disalatkan oleh Sahabatnya saja), koruptor akan masuk neraka meskipun nominalnya kecil, pelaku risywah akan mendapat laknat Allah, dan sedekah dan infak hasil korupsi tidak diterima Allah. Mengenai yang terakhir ini nabi saw bersabda,

عن ابن عمر قال إني سمعت رسول اله (ص) يقول لاتقبل صلاة بغير طهور و لا صدقة من غلول (رو اه مسلم)

Artinya: Dari Ibn 'Umar (diriwayatkan bahwa) ia berkata: Sesungguhnya saya mendengar Rasulullah saw bersabda: Tidak diterima shalat tanpa wudu dan sedekah dari hasil korupsi (gulul) [HR Muslim]. ${ }^{29}$

Rasulullah juga memperingatkan agar koruptor tidak dilindungi atau disembunyikan atau ditutupi perbuatannya. Barang siapa melakukan demikian, maka ia sama dengan pelaku korupsi itu sendiri. Hadis mengenai ini telah dikutip di muka.

\section{Daftar Pustaka}

Abu Talin al-Qadi, "Ilal at-Qadi, Ilal et-Tirmizi (Beirut: 'Alam a Kutub, 1409)

Abu Dawud, Kitab al-Jihad, Bab an-Nahyu 'an as-Satr 'ala Man Galla"; dan at-tabrani, al-Mu'jam al-Kabir (Mousul: Maktabah al-'Ulum wa al-Hikam, 1983).

\footnotetext{
${ }^{29}$ Muslim, op.cit., I: 204, hadis no. 224, 'Bab Wujub at-Taharah li as-Salah".
}

30 
Alatas, Korupsi: Sifat, Sebab dan Fungsi, alih bahasan Nitworno (Jakarta: LP3ES, 1987)

-------, Korupsi: Sebuah Penjelajahan dengan Data Kontemporer, alih bahasa Al Ghozie Usman (Jakarta: LP3ES, 1975)

Al-Bukhari, Sahih al-Bukhari (Beirut: Dar al Ibn Kasir, 1987)

Al-Jashshash, Ahkam al-Quran (Bairut: Dar Ihya' at-Turas al-Arabiy, 1405 H)

An-Nawawi, Syarh an-Nawawi 'ala Sahih Muslim (Beirut: Dar Ihya at-Turas alArabi, 1392 H), XII: 219).

As-Syafi'i, Al-Umm (Beirut: Dar al-Fikr, 1990) Juz II: 63.

Asy-Syaukani, Nail al-Autar (Beirut: Dar al-Jil, 1973) IX: 172

Basyaib dkk (ed.), Mencuri Uang Rakyat: 16 Kajian Korupsi di Indonesia Buku 1 (Jakarta: Yayasan Akasara, 2001)

Horby, oxford Advanced Learner's Dictionary, edisi ke-4 (Oxford: Oxford University Press, 1989)

Ibn Hajar, Fath al-Bari (Beirut: Dar al-Ma'rifah, 1379), V: 221 dan XIII: 164.

Ibn Mandah, al-Imam (Beirut: Mu'assasah as -Risalah, 1406)

Robert Klitgaard dkk., Penuntun Pemberantasan Korupsi dalam Pemerintahan Daerah, alih bahasa Masri Maris (Jakarta: Yayasan Obor dan Patnership for Governance Reform in Indonesia, 2002)

Singgih, Duniapun Memerangi Korupsi (Tangerang: Pusat Studi Hukum dan Bisnis Universitas Pelita harapan, t.t)

Sudirman Said dan Nizar Suhendra, "Korupsi dan Masyarakat Indonesia”, dalam Hamid Basyaib dkk (ed.), Mencuri Uang Rakyat: 16 Kajian Korupsi di Indonesia Buku 1 (Jakarta: Yayasan Akasara, 2001) 